\title{
Actor Positions on Primary and Secondary International Forest-related Issues Relevant in Indonesia
}

\author{
Agung Wibowo ${ }^{1,2} \&$ Lukas Giessen ${ }^{2}$ \\ ${ }^{1}$ Department of Forestry, Faculty of Agriculture, University of Palangka Raya, Indonesia \\ ${ }^{2}$ Chair of Forest and Nature Conservation Policy, University of Goettingen, Germany \\ Correspondence: Agung Wibowo, Chair of Forest and Nature Conservation Policy, University of Goettingen, \\ Buesgenweg 3, 37077 Goettingen, Germany. Tel: 49-55-1391-3391. \\ E-mail: agung.wibowo@stud.uni-goettingen.de
}

Received: February 26, 2015 Accepted: March 10, 2015 Online Published: April 15, 2015

doi:10.5539/jsd.v8n3p10 URL: http://dx.doi.org/10.5539/jsd.v8n3p10

\begin{abstract}
Over the last 20 years a considerable number of international forest-related policies has evolved, collectively referred to as the international forest regime complex. The objectives of this study are to identify the most relevant international forest-related issues discussed in Indonesia as well as the most active actors and their positions on these issues. The empirical methods used include content analysis of Indonesian newspapers, national expert journals, expert mailing lists, and international organizations' position papers. In addition, experts were interviewed to verify and complement the data. As a result, three primary forest-related international issues in Indonesia are identified, namely: timber legality; climate change including REDD initiative; and oil palm plantation and its environmental aspects; and the other four considered as secondary issues, namely: harmonization of wood and forest certification schemes; land use change; forest and species conservation; and deforestation and decentralized forest governance. Public and expert deliberations are found to differ regarding the depth of information as well as their immediate importance for the people and their long-term objectives. The Ministry of Forestry and, surprisingly, the Ministry of Trade are the most active actors in these issues. The main lines of conflict lie between forest utilization interests which are supported by the Ministry of Forestry, Ministry of Trade, oil palm and wood industry associations face-to-face with forest conservation interests powered by WWF and Greenpeace.
\end{abstract}

Keywords: international issues, forest policy, international forest regime complex, Indonesia

\section{Introduction}

Recent forest governance presents in many arena has involved more actors spreading from state representatives, intergovernmental organizations, treaty secretariats, multilateral financial institutions, nongovernmental organizations, as well as business and industry groups (Chasek et al., 2014) and assembling transnational interests into a unique forest regime (Overdevest \& Zeitlin, 2014a; 2014b). Krasner (1982) defines international regimes as "a set of implicit or explicit principles, norms, rules, and decision-making procedures around which actors' expectations converge in a given area of international relations." Simply put and applied to the field of forest policy, this theory describes and analyses international cooperation, primarily among states, and how internationally agreed principles, norms and rules become relevant in national contexts (Smouts, 2008). International regimes are designed in order to influence state behavior including their implementation through national action and policies (Bernstein \& Cashore, 2012; Giessen, 2012; Giessen et al., 2014). However, every country does not necessarily have equal influence in the arena of international diplomacy when advancing its interest, and eventually politically weak countries have to accept unsatisfactory international agreements (Lindstad \& Solberg, 2010). A basic question, however, remains: are international commitments made relevant, implemented and enforced in individual countries? And how are specific issues of the international forest regimes complex (IFRC) put on the political agenda in public and expert networks and their deliberations.

Humphreys (2006) identifies an international forest regime complex (IFRC) which consists of the following elements: forests as a carbon sink under the United Nations Framework Convention on Climate Change (UNFCCC) regime; protection of endangered species under the Convention on International Trade in Endangered Species of Wild Fauna and Flora (CITES) regime; concerning indigenous and tribal people under 
the regime of ILO Convention No. 169; sustainable forest management issues under the United Nations Forum on Forest (UNFF) regime; trade liberalization of forest products under the World Trade Organization (WTO) and General Agreement on Tariffs and Trade (GATT) regime; land management issue under the Convention to Combat Desertification (CCD) regime; conservation of forest biodiversity as an issue under the Convention on Biological Diversity (CBD) regime and the International Union for Conservation of Nature (IUCN) regime; and chain of custody rules under the private Forest Stewardship Council (FSC) regime.

Each of these forest-related regimes has not necessarily been established simultaneously in all countries signatory to the respective agreements. The Global Forest Expert Panel on the International Forest Regime mentions a number of regimes influencing forest-related policy in several countries (Rayner et al., 2010; similar McDermott et al., 2010a; 2010b). Indonesia, the third-largest tropical rainforest country and the largest tropical lumber producer (UN-REDD, 2012; ITTO, 2011) is also influenced by diverse interests in its forests (Nurrochmat, 2005; Maryudi et al., 2012; Brockhaus et al., 2012). Identification of the major domestic political issues related to international forest policies, the actors involved and their positions are then crucial to understand the actual implementation of the IFRC and its specific components in Indonesia (Note 1).

Based on circumstance, the objectives of this article are to identify the most relevant international forest-related issues discussed in Indonesian public and expert deliberations, and to identify the most active actors in these deliberations and their positions on the issues noted. In doing so, the authors are able to identify which parts of the international forest regime complex (IFRC) are currently the most relevant in Indonesia and which actors might have an interest in creating the ways in which the IFRC is implemented in Indonesia.

\section{Theoretical Approach}

"Actor" in this study refers to an individual person, governmental or non-governmental organization with a stake in any forest-related policy. Actors have their own interests which are not always precisely displayed in public arena (Krott, 2005). Public bureaucracies (e.g. a ministry) have dual goals: they strive for public service according to their mandates and are pursuing informal organizational goals. Due to these goals, public bureaucracies compete for resources, political domains and influence (Peters, 2010). To reach their goals successfully, actors seek other actors with (rather) similar interest, set up coalitions, raise bargaining positions and gain power. In this context, mass media could be used as a channel to send signals of preference and positions to other actors.

Issue is a specific problem and could be a starting point of a forest policy process (Sadath \& Krott, 2012). Issue arises because actors succeed in getting their goals onto the political agenda. They are rooted in conflictual underlying interests of the actors and manifest in public or semipublic deliberations of actors. An issue may come from within or beyond the country, depending on its scope and urgency. In this study, an international issue relevant in Indonesia means a specific issue comes from both national and international levels, and it has goals, measures, assumed effect, implementing actors and related to the global agenda on forest in Indonesia. An issue brought by powerful actor has a big opportunity to go into agenda setting, policy formulation then convert into government policy (Howlett \& Ramesh, 1995). Accordingly, issue and actor cannot be separated. Ojha et al. (2009) suggest redistributing cultural/ideological power to actors with less power in order to raise the quality of deliberations.

Steffek (2009) identifies five groups involved in influencing policy making, viz.: representatives of the state, independent experts, activists and lobbyists, journalists and citizens. Each has diverse power in policy making process. Yet, their voices could be even louder if sounding through mass media. Contrarily, the goals which are only delivered in actors' private spheres will fail in showing real political orientation, especially to the public (Krott, 2005). According to this, any statement from actors through mass media can be seen as their initial positions in a specific issue recorded by public. An actor's statement in expert deliberations draws more concrete position of the actor and less bias although, due to their hidden agenda, it may differ from which was published in public mass media.

The Method section describes in detail how the study was conducted, including conceptual and operational definitions of the variables used in the study, Different types of studies will rely on different methodologies; however, a complete description of the methods used enables the reader to evaluate the appropriateness of your methods and the reliability and the validity of your results, It also permits experienced investigators to replicate the study, If your manuscript is an update of an ongoing or earlier study and the method has been published in detail elsewhere, you may refer the reader to that source and simply give a brief synopsis of the method in this section. 


\section{Methodology}

In order to map the international forest related issues in Indonesia, this research distinguishes between deliberations of actors made either in public, such as newspapers, or in a more limited quasi-public arena, such as in expert media. Both differ regarding their degree of publicity and hence can be used differently by actors, e.g. by mobilizing the general public or by discussing detailed issues in expert circles as a selected audience. The authors consider articles/information published by these sources of data within publication period of 2008 and 2012. The public deliberation is derived from magazines and newspapers easily accessible to a wide public audience. For analyzing public deliberations, the authors take two steps. First, choose two national newspapers in the Indonesian language, viz. Media Indonesia and Kompas, and a national newspaper in English, namely The Jakarta Post (Note 2). The combination of keywords hutan ("forest"), kayu ("wood"), internasional ("international") and global were inserted on each newspaper's search engine to elicit 200 first set of relevant articles in order to identify relevant international issues within Indonesian public deliberation. The determination of relevance of an article depended upon the connection of its content with international forest-related issues in Indonesia.

Second, based on identified keywords in the first step, the Google search engine was employed to find more relevant and concrete articles and comments. As an example, when an article in the selected newspapers talks about timber legality, it actually discusses SVLK (Sistem Verifikasi Legalitas Kayu), FLEGT (Forest Law Enforcement, Governance and Trade) and VPAs (Voluntary Partnership Agreements) implementation and the debates around it. The authors then put SVLK, FLEGT and VPA into Google to collect a wider discussion. Only articles from public mass media were considered in order to map the public deliberation on a given issue.

To explore the expert deliberations on international forest-related issues in Indonesia the authors collected data from four sources.

First, interviewed experts whose deeper knowledge on forestry-related issues and international policy influences on Indonesian forestry policies respondents included senior lecturers from Bogor Agricultural University (IPB) and Gadjah Mada University (UGM) (each one person); senior advisor of the World Bank in Jakarta; senior advisor of the Ministry of Forestry; high official at the Ministry of Forestry; administrator Indonesian forester mailing list; editor at Indonesian forestry journal, and Minister of Forestry. Interview is required as supplementary method to verify specific data from other sources and was used to distinguish between primary issues of political relevance and the secondary ones. Interviewees were selected based on quick and ease of field access. To each of them, the authors posed two questions: (1) what are the rules/agreements/policies/issues at the international level that are currently relevant for forest, forestry or forest-related policy making in Indonesia? (2) How are these issues relevant in Indonesia?

Second, data from professional journals in the fields of forestry, agriculture and conservation were collected to catch the discussion circulating among these experts' networks. These journals are Majalah Kehutanan Indonesia, Tabloid Agro Indonesia and Mongabai (Note 3). Majalah Kehutanan Indonesia (Indonesian Forestry Magazine) is a monthly magazine published by the Ministry of Forestry. All articles it contained from 2008 to 2011 were examined and only those with international pertinence to be considered. Agro Indonesia is a weekly tabloid, published since June 2004 and widely read by practitioners and policy analysts in the fields of forestry, agriculture, fishery, plantations and husbandry. All relevant topics from February 2009 (the first online edition) to October 2012 were screened.

Third, the discussions among academics, observers and practitioners on the Indonesian forester interactive mailing list (rimbawan-interaktif@yahoogroups.com) were also taken into account. This mailing list was founded in 2000 and had 1406 members as of September 2014. The authors only considered entries within years 2010 until 2014.

Fourth, any publications from international organizations related to the Indonesian forest sector such as Food and Agriculture Organization (FAO) and International Tropical Timber Organization (ITTO) files were also studied.

Based on the data from all sources (interviews, professional journals, environmental and conservation news sites, mailing list archives and international publications), the specific issues were identified. Selected issues may partly overlap in categorization due to difference context or focus of deliberations. From the public and expert data sources, the authors elicited and interpreted the main actors' positions on the issue if applicable. The absence of any relevant news in public media indicating the issue was not important for public or had not become a public concern. 


\section{Results}

By scrutinizing source of data above, the authors identify seven primary and secondary issues on international policies relevant to forests in Indonesia. The primary issues are: timber legality, oil palm plantation and its environmental aspects, and climate change including REDD initiative; while the secondary issues consist of harmonization of wood and forest certification schemes, land use change, forest and species conservation, and deforestation and decentralized forest governance (Appendix A). Detailed descriptions for each issue follow below, distinguishing between public and expert deliberations and summarizing the positions taken by the main actors in each issue.

\subsection{Primary International Forest-related Issues}

\subsubsection{Timber Legality}

Forest Law Enforcement, Governance and Trade (FLEGT) is the European Union (EU) policy to combat illegal logging and illegal trade in forest products. This includes the adoption of the FLEGT Action Plan (2003) which contains EU's commitment to develop a Voluntary Partnership Agreement (VPA) with timber producing countries to prevent illegal timber products from entering the European market. On 4 May 2011, the Indonesian Minister of Forestry and the EU Trade Commissioner signed the FLEGT document. Through this agreement, the EU will ensure free and unrestricted access to all FLEGT-licensed timber products from Indonesia. In order to implement the agreement, the Indonesian government developed the Timber Legality Verification System (Sistem Verifikasi Legalitas Kayu or SVLK). It is up to the EU now to recognize SVLK as a tool to determine the legality of Indonesian timber products exported to the EU.

Public deliberation

The agreement lists 48 kinds of certified wood products under that SVLK scheme that may be imported without restriction into EU countries (Media Indonesia, 2011a; Harian Terbit, 2012a). The government stated that this policy was fully supported by the industry. According to the Director of Processing and Marketing of Forest Products of the MoF, by the end of 2011 there were about 125 timber companies implementing SVLK along with 30 forest concessionaires and timber estates. An industrial group represented by Director of Riau Andalan Pulp and Paper said they supported the government's efforts to encourage timber legality verification standards to be recognized internationally (Media Indonesia, 2011a; 2011b). At the SVLK launching event, the Minister of Forestry also claimed SVLK would prevent timber laundering in other countries (Kompas, 2012a). Hence, the government expects the program would be supported by small and medium scale enterprises (SMEs). For that purpose government allocated IDR 3 billion in financial assistance for handicraft producers in Bali and furniture makers in Jepara (The Jakarta Post, 2012a). The government committed to implementing SVLK for forest unit management and processing industries in December 2012 and 2013 respectively, and rejected a proposal from the APHI (Asosiasi Pengusaha Hutan Indonesia or Association of Indonesian Forest Concessionaires) and Asmindo (Asosiasi Industri Permebelan dan Kerajinan Indonesia or Indonesian Furniture Industry and Handicraft Association) to delay (Harian Terbit, 2012b; Suara Merdeka, 2012). However, later on, the EU was still reviewing SVLK rules and not yet ready to sign the agreement as of November 2012 (The Jakarta Post, 2012b). Regarding this point, Deputy Minister of Trade said he questioned the readiness of the EU to implement wood export rules, and even bring this case to WTO if they found evidence of unfair trade (Antara, 2012a).

\section{Expert deliberation}

Using SVLK as the sole governmental tool for determining timber legality and applied to all kinds of wood-based products is actually not fully supported by industry groups. The chairman of Asmindo refused enactment of SVLK for furniture products since their raw materials are derived from primary industries that hold legality certificates (Agro Indonesia, 2012a). By contrast, Minister of Forestry felt confident that SVLK was the answer to the Indonesian timber trade's problems and he asked all wood industries to meet it (Majalah Kehutanan Indonesia, 2011a; 2011b). On the other hand, the Conservation Director at WWF Indonesia said that $50 \%$ of consumers in the country ask about wood products legality when they buy it (Agro Indonesia, 2012b).

The third suspension of VPA signing by the EU raised questions. The Chair of the Indonesian Delegation for VPA Negotiation argues that VPA looks like a non-tariff barrier to trade (Agro Indonesia, 2012c). The Director of Forest Production Development and Forest Products Marketing of the MoF also doubted the EU's commitment to reducing illegal logging since the reason for postponement was an administrative matter, namely translating the documents into the 27 languages of EU member countries (Agro Indonesia, 2012d). Furthermore, analysts blamed the severe economic crisis in some EU countries and industry protectionism as the real reasons for SVLK delay (Rimbawan Interaktif, 2012a). Researchers criticised the VPA as disguised trade barriers to 
obstruct Indonesian wood products, especially for pulp and paper. Similarly, the Director of the Forestry Multistakeholder Programme also condemned the EU's postponement of VPA endorsement (Agro Indonesia, 2012c).

In response to the VPA and SVLK controversies, a lecturer at IPB said that the issue was not about legality but legitimacy (Agro Indonesia, 2012e). Other experts and practitioners were still debating whether SVLK had to be implemented, since approximately $40 \%$ of sawmills are illegal and this would affect the legality of wood products (Rimbawan Interaktif, 2012b). They then asked the government to place more emphasis on bilateral agreements rather than waiting for EU agreement on SVLK, since they said EU regulation is not legally binding for its members (Rimbawan Interaktif, 2012c).

There are six groups involved in the timber legality issue, namely the Ministries of Forestry and the Ministry of Trade; primary and large-scale forest industries; Asmindo, APHI and the downstream industries; the European Union (EU); the World Wide Fund for Nature (WWF); and researchers and academics. The government, large-scale companies, environmental groups and the EU support a wood certification programme in order to achieve sustainable forest management. Meanwhile, Asmindo and APHI consider certification for furniture and handicrafts unnecessary because the raw materials they use are legal, and certification would increase production cost and lead to a decline in competitiveness. On the other hand, academics suggested all parties seek the legitimacy of Indonesian timber products with the assurance of forest sustainability.

\subsubsection{Climate Change Including REDD Initiative}

Reducing Emissions from Deforestation and Forest Degradation (REDD) was an approach proposed at Climate Change Conference 13 in Bali in 2007 and amended in 2009 at the Copenhagen Climate Change Summit. It contains mechanisms for REDD and forest-rich countries to earn compensation for preserving their forests. President Yudhoyono, at the G20 Summit in Pittsburgh, filed a voluntary commitment to reduce Indonesia's carbon emissions by $26 \%$ by 2020 , up to $41 \%$ with international assistance. Following the commitment, the government set up 70 programs funded by the state budget to reduce emissions as promised.

\section{Public deliberation}

Climate change has attracted people's attention successfully. The emergence of the REDD initiative, however, raises a lot of pros and cons. Indigenous environmental groups reject REDD and call it "colonialism of forests". They argue that REDD scheme will only seize control of indigenous forest people's land and allow capital owners to occupy it (Kompas, 2009). At provincial level, some governors felt their provinces were appropriate for REDD implementation. Nevertheless, at that time the central government designated only eight provinces for the REDD trial (Kompas, 2011a). In the practice, each stage of REDD implementation program involved many parties and this led to slow progress. Many are worried, since the program was launched and approved internationally (Kompas, 2011b)

Expert deliberation

The Indonesian commitment to reduce carbon emissions concerned the involvement of the Norwegian government. In May 2010, Indonesia and Norway signed a Letter of Intent (LoI) with USD 1 billion of REDD+ funding for emission reduction activities (Majalah Kehutanan Indonesia, 2010). In 2011 the Ministry of Forestry also received a grant of USD 3.6 million from the Forest Carbon Partnership Facility to support Indonesia in reducing greenhouse gas emission by $26 \%$ by 2020 (Majalah Kehutanan Indonesia, 2011c). To meet its commitment the Indonesian government's REDD+ Task Force has done many things, including a logging moratorium on 64 million hectares of primary forests and peatlands and limiting plantation size area (Agro Indonesia, 2011c; 2012i). However, Norway said the effort was not enough and Indonesia must do more (Agro Indonesia, 2012j). Lately, Norway would like to resign from the LoI (Rimbawan Interaktif, 2012e).

Regarding this issue the authors consider there are three most active actors who affecting Indonesia policies, namely the Presidential Delivery Unit for Development Monitoring and Oversight (UKP4) which also leads REDD+ Task Force, the Ministry of Forestry, and scientists. UKP4 has set many policies related to forest utilization and national strategic for REDD implementation. Those policies have wide implications for all REDD activities throughout Indonesia. Meanwhile, the Ministry of Forestry as a technical actor has an important role since forest sector is expected to reduce emission by $14 \%$ of the total national target. Their performance would be significant contribution to the success of REDD implementation. Scientists have much influence through academic discussion and policy formulation.

\subsubsection{Oil Palm Plantation and Its Environmental Aspects}

Indonesia had the biggest area of oil palm plantation with 48\% of world palm oil production in 2012 (Note 4) 
(Majalah Swa, 2012). This status was achieved in 2007 after Indonesian palm oil production exceeded that of Malaysia. At $34 \%$, palm oil has the largest market share compared to other vegetable oils. Palm oil gradually shifted the market share of soybean oil produced by subtropical countries, which only reaches $30.1 \%$ (Media Indonesia, 2010a).

Public deliberation

The high productivity of oil palm plantation which takes around six to ten times compared to other vegetable oils' grown in Europe and the US has been triggering unfair competition among its competitors. The Secretary General of Indonesian Palm Oil Association (Gabungan Pengusaha Kelapa Sawit Indonesia or GAPKI) said that the pressure on the oil has been going on since early 1980s. He detailed that NGOs' allegations ranging from claim that palm oil having high cholesterol, inducing heart disease, causing pollution and destroying orangutan habitats (Media Indonesia, 2010b). The Indonesian government considered that claims of environmental destruction against the Indonesian oil palm plantation as a part of a trade war, which was to be countered by providing more accurate information. The Coordinator Minister for Economic Affairs said the government and industry had to fight against a smear campaign related to palm oil, even bringing unfair trade practices allegations to the World Trade Organization or to bilateral meetings (The Jakarta Post, 2012c). Previously, in 2011, GAPKI resigned from the Roundtable on Sustainable Palm Oil (RSPO) and supported Indonesian Sustainable Palm Oil (ISPO) as an alternative framework standard for palm oil certification, though still allowing their members to stay in RSPO (Bisnis Indonesia, 2011; Republika Online, 2011a). At the APEC CEO Summit 2012 in Vladivostok, a number of developed countries, led by the US, did not approve palm oil as environmental goods. At the time, President Yudhoyono said that palm oil was an environmentally friendly product, but it was blocked by unfair competition (Suara Pembaruan, 2012). In November 2012, Greenpeace indicated Indonesian oil palm companies did not protect the environment, since they did not hold RSPO certificates and were planting in shallow peat land, which however is legal in Indonesia (Antara, 2012b).

\section{Expert deliberation}

Oil Palm plantation issue in the Ministry of Forestry focused more on licensing forestland for plantation and mining. Hence, MoF did not pay much attention to this issue. Conflicts between Indonesian palm oil producers and other vegetable oil producers from Europe and the US have been going more intense and are recognized by Indonesian government as well as GAPKI. The Indonesian Deputy Minister of Trade challenged the EU to conduct research and prove their claim that oil palm destroys the environment and is harmful to health. He even presented scientific data to refute all such claims (Agro Indonesia, 2011a). In addition, the Indonesian government is also awaiting the US response on charges that palm oil did not meet the minimum standard of greenhouse gas emissions reduction (Agro Indonesia, 2012h). This unpleasant business attitude convinced GAPKI to resign from RSPO, since RSPO tends to support consumers' interests. RSPO membership consists $30 \%$ of growers and 70\% of non-growers, while RSPO decisions are based on a majority voice. GAPKI considered RSPO rules as only complicating matters for producers, and consumers did not buy palm oil with RSPO certificates at premium prices (Agro Indonesia, 2011b). GAPKI also suspects RSPO directed non-governmental organizations to protect western countries' interests since they bluntly call for open war against palm oil. Apparently, this conflict would take a long time since President Yudhoyono fully supports expanding oil palm plantations (Investor Daily Indonesia, 2012).

In general, groups involved in palm oil issue polarized into producer and non-producer. Group of producer consists of the Ministries of Forestry, Ministry of Trade, large-scale oil palm companies and their association (GAPKI); while the non-producer group comprises the EU, the USA, and environmental NGOs, to wit WWF and Greenpeace. Surprisingly, buyers' alignment was determined by the groups' campaign through mass media. Although buyers, being rational, like qualitied products at low prices, they do not want to be accused as a group who degrades the environment.

\subsection{Secondary International Forest-related Issues}

\subsubsection{Harmonization of Wood and Forest Certification Schemes}

Issue on timber and forest certification emerged from the need for an information system to assess whether a timber product has been processed through environmentally friendly ways. For this purpose, environmental activists and other groups set up the Forest Stewardship Council (FSC) certification scheme in 1993. By this time, there also emerged other certification schemes such as the Programme for the Endorsement of Forest Certification (PEFC) in Europe, Sustainable Forestry Initiative (SFI) in North America and Lembaga Ekolabel Indonesia (LEI) in Indonesia. All of them are voluntary, which means participants could adopt the standards if they are willing and fulfill the requirements. In 2009, the Indonesian government developed SVLK as a timber 
legality assurance and applied it in 2013 to all wood-based industries. Each certification scheme has specific attributes, such as market acceptance, cost, length of certification process, emphasized aspects, as well as standards flexibility. Business units, however, constantly use economic considerations in choosing affordable schemes in line with profit maximization. For this reason, some of them took more than one certification scheme at once (Bisnis Indonesia, 2012). This leads to a double charge, whereas buyers do not require a specific certification model. There was no any valuable public deliberation to this issue. Conversely, five of seven experts interviewed unequivocally stated that forest and timber certification was an international issue that strongly influenced Indonesian forest policy and practices.

\section{Expert deliberation}

As a matter of fact, the FSC scheme is voluntary and has been adopted by industries that primarily export wood-based products to Europe. Regarding this point, the Deputy Minister of Trade stated that there should be a bridge between mandatory and voluntary schemes so that those who receive SVLK automatically become FSC certified (Agro Indonesia, 2012f). A similar idea was also conveyed by the Executive Director of APHI, since the government was to do so on a voluntary basis (Agro Indonesia, 2012g). Along with the talks, on 6 March 2012, the Indonesia Forestry Certification Coordination (IFFC) introduced the PEFC certification scheme, which is known to have weak environmental criteria compared to the FSC, but was received well in Europe and the US. At present, the issue on harmonization of certification schemes is still on going.

Based on previous information, there are four groups with strong interest in this issue, namely the Ministries of Forestry and Trade; the Indonesian timber industry; the WWF; and certification scheme owners. The Indonesian government must fight for wood products to be accepted in overseas markets. Therefore, trade barriers must be removed, and agreement with buyer countries have to be signed as soon as possible. Meantime, logging companies and other large-scale wood-based industries want their products accepted by the market with or without certification. Nevertheless, the furniture and handicraft industries reject double certification because their raw materials have already been certified, so they expect their products to be certified automatically. And last, certification scheme owners also want to preserve their certification schemes.

\subsubsection{Land Use Change}

Land use change in Indonesia is a warm issue among industrial groups and environmental activists. This comes from the USD 1 billion Letter of Intent (LoI) between Indonesia and Norway that includes moratorium of new forest utilization permits as Indonesian commitment to reduce carbon emissions. As known, the Oslo Agreement on forest moratorium actually applies only to primary forests and peat lands, and effectively began in early 2011 . However, foreign NGOs tried to pressure the government to implement the moratorium on all types of forest, including secondary forests, which then were opposed by palm producers. In this issue, there is no any meaningful debate arising in public media.

\section{Expert deliberation}

The Chairperson of Indonesian Enterprises Association (Apindo) said that the President had to prioritize national interests rather than satisfy foreign insistence to implement the moratorium on all type of forests. The Association of Indonesian Palm Oil (GAPKI) stated that the moratorium on oil palm development and expansion was not possible since this commodity delivered considerable economic and social benefits (Agro Indonesia, 2010). In May 2011, President Yudhoyono issued Presidential Decree No. 10, delaying all new utilization permits within primary forest and peat lands for two years, and instructed the Minister of Forestry to improve forest management policies (Majalah Kehutanan Indonesia, 2011d). However, the Secretary-General of the Ministry of Forestry and Greenpeace both said that the moratorium had to expand beyond two years (Mongabai Indonesia, 2012b). On the other hand, the Indigenous Peoples' Alliance of the Archipelago (AMAN) took this opportunity to have included 6 million hectares of customary land into the New Integrated National Map (Mongabai Indonesia, 2012c). Some experts argue that the government should commit to a moratorium in all of primary forest and peat land area in order to meet the presidential pledge to reduce carbon emission by $26 \%$ in 2020. They also ask the government to increase palm oil production through intensification rather than extensification (Rimbawan Interaktif, 2012d).

Based on these findings, there are five groups strongly involved in this issue. First, the Ministry of Forestry as the authority in control of forestland use; second, plantation companies and other business groups who need vast land resources to running their business; third, indigenous people's groups concerned with keeping their land from encroachment by industry. Environmental organizations such as Greenpeace also pay attention to the land-use change issue to make sure the forest moratorium is implemented properly. Lastly, scientists raise the government's awareness of how to balance both economic growth and forest and environmental sustainability. 


\subsubsection{Forest and Species Conservation}

Forest degradation and deforestation caused by fires, improper land use and logging activities have deflated biodiversity in Indonesia and lead to some species being endangered or extinct. The Indonesian government, people and communities in and around forests, business groups and conservation organizations then put much effort to prevent its deterioration.

Public deliberation

There were not so many articles on forest, land and species conservation in public mass media. If any, they put more emphasis on conflicts of interest in the conservation field, not conservation activities themselves. Conservation activities were undertaken to protect nature and build livelihood. For example, a breeding center for the endangered Bali starling was launched by Begawan Foundation in Bali (The Jakarta Post, 2011). They bred local birds with others to enhance genetic diversity. In Lampung, the Artha Graha Network in cooperation with the Ministry of Forestry conserve forest for tigers, elephants, gibbons and other wildlife (Media Indonesia, 2011c). Other groups take indirect activities to conserve nature, such as the Indonesian Wild Birds Reservation, which launched a postage stamp series featuring endangered Indonesian birds (The Jakarta Post, 2012d). At the international level, the United States erased USD 28.5 million of Indonesian debt in a debt-for-nature swap agreement, namely the transfer of debt used for forest conservation. Previously, the US government wrote off USD 19.6 million of Indonesian debt for forest conservation focusing on the 13 national parks on Sumatra (Republika Online, 2011b).

\section{Expert deliberation}

The Ministry of Forestry has agencies for conserving nature under the supervision of the Directorate General of Forest Preservation and Natural Conservation. They are very concerned about endangered species such as Sunda pangolin (Manis javanica), Badak Jawa (Rhinoceros sondaicus), and Elang Jawa (Spizaetus bartelsi) in Java; Badak Sumatra (Dicerorhinus sumatrensis) in Sumatra; Cendana (Santalum album) in East Nusa Tenggara; snake-necked turtle (Chelodina mccordi) in Rote Island and tiger and orchid species (Majalah Kehutanan Indonesia, 2008; 2009a; 2009b; 2009c; also Mongabai Indonesia, 2012a). Most articles about species conservation were linked to the species status according to the International Union for Conservation of Nature (IUCN) or CITES (the Convention on International Trade in Endangered Species of Wild Fauna and Flora). On the Indonesian forester mailing list, the discussions about conservation circulate around the forest as the habitat of animals and plants and the function of forests in mitigating natural disaster. Discussion also arose when mass media revealed violations committed by companies, such as the poaching of orangutans (Pongo pygmaeus) when opening oil palm plantations (Rimbawan Interaktif, 2012f; 2012g).

Only three actors with two meaningful roles were present in this issue, namely the Ministry of Forestry versus forest companies and conservation organizations. Mass media consider their activities important for arousing public awareness in environmental protection. Although environmental organizations and scientists talk about this issue, their roles were not very noticeable. In fact, the latter actors did not have a lot of influence on the issue, since mass media only reported the actors who took real action as preserving environment.

\subsubsection{Deforestation and Decentralized Forest Governance}

The high rate of deforestation in Indonesia and its impact has become a concern of the world. Sunderlin and Resosudarmo (1996) mentioned meaningful publications stated that deforestation in the 1990s was caused mainly by shifting cultivation, transmigration growth of population. Similar conclusion derived by data from the Ministry of Forestry indicated that $66 \%$ of deforestation was caused by commercial, local and subsistence agriculture (Kissinger et al., 2012). However, issues related to deforestation are often associated with corruption, weak law enforcement, inappropriate policy and the inability of central government to manage the forest (Suparna, 2001; FWI \& GFW, 2002). These arguments then led to a rethink of authority sharing between central and local governments in forest management. In CGI meeting in 2001, forestry decentralization was agreed as a condition of loan debt. The central government then issued a series of regulations called forest policy reform. However, the deforestation rate has even peaked in the decentralization era (Nurrochmat, 2005).

Public deliberation

The Secretary General of APHI recognized local autonomy as the driving factor of deforestation. He said regional autonomy provides the opportunity for regents to issue concessions of less than 30 thousand hectares according to Law No. 22/1999 on Regional Government. Unfortunately, these licenses did not meet with sustainable forest management practices, and massive deforestation occurred in most of the forest-rich districts (Media Indonesia, 2012). Supporting this claim, some of former heads of districts have been tried in court for 
forestry-related crimes (Kompas, 2012b). Environmental organizations such as WWF, Indonesia Working Group on Forest Finance (IWGFF) and Transparency International Indonesia (TII) stated that decentralization opened space for corruption and collusion in natural resource utilizations (Gatra, 2012). The Director General of Forest Protection and Nature Conservation of the MoF reported that potential losses due to inappropriate permits during the era of decentralization reached IDR 276.4 trillion, including 770 illegal logging cases and 1724 for mining from 2004 until 2012 in eight provinces (Kompas, 2012c).

Expert deliberation

The United Nations Environment Programme (UNEP)'s report entitled Green Carbon, Black Trade mentioned rampant deforestation and illegal timber trade in various parts of the world caused by organized crime. In Indonesia, it was caused mainly by corruption at upper and lower state levels and system failure (Nellemann \& INTERPOL Environmental Crime Programme, 2012). The MoF realized the decentralization process has not shown meaningful progress yet. Conflicts and disharmonized power sharing between central and local governments have enlarged opportunities in unsustainable forest utilizations and led to new pressure on forests (Kementerian Kehutanan, 2010). On the other hand, the central government seems to be very careful in setting new policies to avoid accusations of recentralization. Apparently, decentralization brought trouble and confusion for Indonesia in the middle of a desire to create greater regional autonomy (Kadjatmiko, 2008). Many researchers emphasized formulating suitable policy regarding forest decentralization. For instance, CIFOR has conducted 14 studies on decentralization and forest throughout Indonesia during period 2001-2005.

The central and local governments and environmental organizations are the main actors playing important roles in this issue. The central government has to share its power with local governments for decentralization to work. In the meantime, it also faces heavy international pressure to manage the environment well. Local governments for their part harness unstable decentralization to profit from forest utilizations. On this point, environmental organizations come and use national and international publications to warn about long-term environmental damage.

\section{Discussion}

\subsection{Public versus Expert Deliberations}

There are three differences in how the issues were presented in public and expert discourse deliberation. First, public mass media did not pay much attention to issues that did not have direct and immediate importance for the citizen, i.e.: harmonization of wood and forest certification schemes and land use change. This means that public mass media consider public preferences for their articles and ignore irrelevant topics for short-term interests of society. Second, public deliberations also differ from expert deliberations in terms of the depth of information. Third, public deliberations only touch debates on policymaking process and its implementation, while the expert's give long-term strategic discussions, policy options, studies on policy impacts and dialogue space among interested groups. This deliberative behavior is quite similar to what happened in Bangladesh, Brazil, Bolivia, Peru, and other countries (see: Kleinschmit, 2012; Leipold, 2014; Medina et al., 2009; Sadath, 2012; Sadath et al., 2013; Sadath \& Krott, 2012).

\subsection{The Most Active Actors}

The Ministry of Forestry is the most active actor in all issues. Another active actor is the Ministry of Trade, which actively involved in three issues, namely timber legality, harmonization of wood and forest certification scheme, as well as oil palm plantation and its environmental aspects. It indicates that forest-related issues at an international level are closely related to international trade and business (Humphreys, 2009). In these cases, the Ministries of Forestry as well as the Ministry of Trade work in similar directions, primarily in order to get Indonesian natural products into EU and the US markets (Kementerian Kehutanan, 2012a; 2012b; Nurrochmat et al., 2014; Cashore \& Stone, 2012; Iben et al., 2014). This is surprising as the theory of bureaucratic politics suggest only a single actor has dominant role in a particular sector (Peters, 2010) and intersection of responsibilities among state bureaucracies will create conflict of interests and unproductive contestation (Sahide \& Giessen, 2015; similar Ongolo, 2015; Hogl et al., 2009). Future studies must scrutinize this relationship not based on discursive contributions, but on on-going politics.

This study also finds industrial groups, namely wood-based industry and oil palm plantation groups, involved in five of the seven issues. Most industries support foreign trade policies issued by the Ministry of Forestry and the Ministry of Trade even though some of them disagree on the certification policy for downstream industries (similar Obidzinski et al., 2014). However, they are in conflict with WWF and Greenpeace, who oppose these industries as destructive to the forest and environment. Industrial groups still demand proof of these allegations. 
Environmental groups were another active actor that was present in almost issues. In the case of timber legality and harmonization of wood and forest certification schemes, both industry and WWF tend to a similar direction although each group has its own interests.

\subsection{The "Missing” Actors}

The roles of scientists and indigenous people were not apparently clear on these issues. Scientists' role in analyzing issues is limited to scientific and policy discussions among themselves, not in the public media. This finding is in line with prior findings on the limited impact of scientific experts on public deliberation (e.g. Sadath, 2012; Grundmann, 2009; Giessen et al., 2009; Hasanagas, 2014; Ekayani et al., 2015). Meanwhile, Aliansi Masyarakat Adat Nusantara (AMAN), as a representative of indigenous people, tries to circulate information regarding their predicament through several channels of group and social media. However, the complexity of the social order and conflicting interests among indigenous people makes this problem quite difficult to rise in public mass media, let alone at an international level.

\subsection{Issues in International Forest Regime Complex versus Domestic Issues}

The results suggest that the issues of timber legality, forest conversions, and climate change are now become the major topics discussed by the MoF. These issues demonstrate that the MoF puts more concern on production function of forest rather than to its non-economic functions. Pressures by environmental NGOs through their international networks still unable to bring more conservational and social issues -as elements of sustainable forest management- like endangered species protection, poverty alleviation of forest-dependent people, and local people rights' recognition into the MoF's priority programs. This fact strengthens claim mentioning although many issues available in international negotiations on and related to forest resource (Humphreys, 2006), bureaucracies always choose the most appropriate ones, according to their interests. It also clarifies that some issues may be applicable for certain country within specific period, while some others are not (Giessen et al., 2014).

\section{Conclusion}

This paper has identified seven current international forest-related issues in Indonesia: timber legality; harmonization of wood and forest certification schemes; oil palm plantation and its environmental aspects; land use change; climate change including REDD initiative; forest and species conservation; and deforestation and decentralized forest governance. These issues are also observed work in Bangladesh (Rahman \& Giessen, 2014) and Argentina (Burns \& Giessen, 2014), and strengthen a notion mentioning recent global initiatives on forest spin around issue of forest sustainability, legal timber and REDD+ (McDermott, 2012). Two issues that are more technical as well as potentially contentious, specifically harmonization of wood and forest certification schemes and land use change were not present in public deliberations, but rather remained limited to expert circles. Hence the IFRC seems to be relevant in many ways in Indonesia. The issues identified do cover a wide range of policy domains described by Humphreys (2006) and Giessen (2012). In Indonesia, global climate agreements are made relevant through REDD, endangered species conservation is discussed and free trade issues are touched upon by timber legality and certification issue. However, elements of indigenous people, desertification, CBD and SFM are not discussed in Indonesian public and expert deliberations.

Altogether the issues show that the most active actors in public and expert deliberations are the Ministry of Forestry and the Ministry of Trade, environmental NGOs like WWF and Greenpeace as well as wood and palm oil industry groups. This suggests that the competition of public bureaucracies and their societal clientele (i.e. ministries, see Peters, 2010; Rayner et al., 2001; Hogl et al., 2009; Giessen 2010a; 2010b; and Giessen \& Krott, 2009; Krott \& Hasanagas, 2006) is an important driver of forest-related issues and politics in Indonesia. Their contribution to the issues indicates a relatively weak coalition on forest protection, whereas forest utilizations and trade interests seem to be rather strong. Moreover, the main lines of conflict as represented in the issues lie between forest utilizations (e.g. for profitable timber or other land use) and forest conservation, which is in line with research by Winkel (2007). This study only analyses the issues measured by more or less public statements in newspapers, expert journals and so forth. These only indicate the formal claims and positions of the actors which they are willing to display in more or less public deliberations in public and expert arena (Krott, 1990; Kleinschmit, 2012). Based only on this data on formal statements, the authors draw conclusions on which issues from the IFR are made relevant in Indonesia. Other issues which may become relevant based on informal goals of specific actors cannot be revealed by this study.

\section{Acknowledgments}

This research has been kindly supported by the Indonesia Ministry of Research and Higher Education (Dikti), the 
Eva Mayr-Stihl Stiftung, the German Research Foundation under the project "Fragmentation of the International Forest Regime Complex" (PAK813), as well as the German Academic Exchange Service (DAAD).

\section{References}

Agro Indonesia. (2010). GAPKI: Tak mungkin moratorium pengembangan sawit. Retrieved from http://agroindonesia.co.id/2010/05/27/gapki-tak-mungkin-moratorium-pengembangan-sawit/

Agro Indonesia. (2011a). RI tantang UE teliti kebun sawit. Retrieved from http://agroindonesia.co.id/ 2011/10/25rspo-untuk-kepentingan-siapa/

Agro Indonesia. (2011b). RSPO untuk kepentingan siapa? Retrieved from http://agroindonesia.co.id/ 2011/10/25/rspo-untuk-kepentingan-siapa/

Agro Indonesia. (2011c). Seluas 64 juta hektare hutan di-verboden. Retrieved from http://agroindonesia.co.id/ 2011/05/23/seluas-64-juta-hektare-hutan-di-verboden/

Agro Indonesia. (2012a). Legalitas yang memangkas daya saing? Retrieved from http://agroindonesia.co.id/ 2012/01/25/legalitas-yang-memangkas-daya-saing/

Agro Indonesia. (2012b). Lokal pun mulai sadar lingkungan. Retrieved from http://agroindonesia.co.id/ 2012/06/19/masalah-indonesia-legitimasi-bukan-legalitas/

Agro Indonesia. (2012c). Indonesia akan paksa implementasi VPA. Retrieved from http://agroindonesia.co.id/ 2012/10/02/indonesia-akan-paksa-implementasi-vpa/

Agro Indonesia. (2012d). Indonesia pertanyakan komitmen Uni Eropa. Retrieved from http://agroindonesia.co.id/2012/10/02/indonesia-pertanyakan-komitmen-uni-eropa

Agro Indonesia. (2012e). Masalah Indonesia: legitimasi, bukan legalitas. Retrieved from http://agroindonesia.co.id/2012/06/19/masalah-indonesia-legitimasi-bukan-legalitas/

Agro Indonesia. (2012f). Pengusaha hutan makin peduli kelestarian. Retrieved from http://agroindonesia.co.id/ 2012/06/19/pengusaha-hutan-makin-peduli-kelestarian/

Agro Indonesia. (2012g). Berharap ada pengakuan bersama. Retrieved from http://agroindonesia.co.id/ 2012/06/19/pengusaha-hutan-makin-peduli-kelestarian/

Agro Indonesia. (2012h). AS ulur waktu soal minyak sawit. Retrieved from http://agroindonesia.co.id/ 2012/06/27/as-ulur-waktu-soal-minyak-sawit/

Agro Indonesia. (2012i). UKP4 pangkas luas pemilikan kebun. Retrieved from http://agroindonesia.co.id/ 2012/08/28/ukp4-pangkas-luas-pemilikan-kebun/

Agro Indonesia. (2012j). Norwegia kritik moratorium RI. Retrieved from http://agroindonesia.co.id/ 2012/05/29/norwegia-kritik-moratorium-ri

Antara. (2012a). Kemendag akan pertanyakan kesiapan SVLK Uni Eropa. Retrieved from http://www.antaranews.com/berita/335804/kemendag-akan-pertanyakan-kesiapan-svlk-uni-eropa

Antara. (2012b). Greenpeace keluarkan rapor perusahaan sawit di Indonesia. Retrieved from http://www.antaranews.com/berita/341119/greenpeace-keluarkan-rapor-perusahaan-sawit-di-indonesia

Bernstein, S., \& Cashore, B. (2012). Complex global governance and domestic policies: Four pathways of influence. International Affairs, 88(3), 585-604. http://dx.doi.org/10.1111/j.1468-2346.2012.01090.x

Bisnis Indonesia. (2011). Gapki resmi keluar dari RSPO. Retrieved from http://www.bisnis.com/ articles/gapki-resmi-keluar-dari-rspo

Bisnis Indonesia. (2012). Pengusaha kehutanan minta model sertifikasi lacak balak kayu disinergikan. Retrieved from http://www.bisnis.com/articles/pengusaha-kehutanan-minta-model-sertifikasi-lacak-balak-kayu-disinergikan

Brockhaus, M., Obidzinski, K., Dermawan, A., Laumonier, Y., \& Luttrell, C. (2012). An overview of forest and land allocation policies in Indonesia: Is the current framework sufficient to meet the needs of REDD+? Forest Policy and Economics, 18, 30-37.

Burns, S. L., \& Giessen, L. (2014). Identifying the main actors and their positions on international forest policy issues in Argentina. Bosque, 35(2), 163-173. http://dx.doi.org/10.4067/S0717-92002014000200004

Cashore, B., \& Stone, M. W. (2012). Can legality verification rescue global forest governance? Analyzing the potential of public and private policy intersection to ameliorate forest challenges in Southeast Asia. Forest Policy and Economics, 18, 13-22. http://dx.doi.org/10.1016/j.forpol.2011.12.005 
Chasek, P., Downie, D. L., \& Welsh Brown, J. (2014). Global environmental politics (6th ed.). Boulder: Westview Press.

Ekayani, M., Nurrochmat, D. R., \& Darusman, D. (2015). The role of scientists in forest fire media discourse and its potential influence for policy-agenda setting in Indonesia. Forest Policy and Economics. http://dx.doi.org/10.1016/j.forpol.2015.01.001

Forest Watch Indonesia [FWI] \& Global Forest Watch [GFW]. (2002). The state of the forest: Indonesia. Jakarta and Washington: Forest Watch Indonesia [FWI] \& Global Forest Watch [GFW].

Gatra. (2012). Korupsi \& pencucian uang pun jadi penyebab degradasi hutan. Retrieved from http://www.gatra.com/nusantara/nasional/20180-korupsi-pencucian-uang-pun-jadi-penyebab-degradasi-hutan.html

Giessen, L. (2010a). Regional governance für ländliche Räume-innovativer ansatz, politischer Gegenwind und der Weg vorwärts. Raumforschung und Raumordnung, 68(1), 3-14. http://dx.doi.org/10.1007/s13147-009-0009-7

Giessen, L. (2010b). Regional forest governence-potentials for forestry and political drivers in integrated rural development policy. Goettingen: Goettingen University Press, 313pp.

Giessen, L. (2012). Temporary governance and persistent government-rural policy integration in pilot and mainstream funding programmes. In K. Hogl, E. Kvarda, R. Nordbeck, \& M. Pregernig (Eds.), Environmental governance: the challenge of legitimacy and effectiveness (pp. 155-177). Massachusetts: Edward Elgar. http://dx.doi.org/10.4337/9781849806077.00017

Giessen, L., \& Krott, M. (2009). Forestry joining integrated programmes? A question of willingness, ability and opportunities. Allgemeine Forst- und Jagdzeitung, 180(5-6), 94-100.

Giessen, L., Kleinschmit, D., \& Böcher, M. (2009). Between power and legitimacy-discourse and expertise in forest and environmental governance. Forest Policy and Economics, 11(5-6), 452-453. http://dx.doi.org/10.1016/j.forpol.2009.08.002

Giessen, L., Krott, M., \& Möllmann, T. (2014): Increasing representation of states by utilitarian as compared to environmental bureaucracies in international forest and forest-environmental policy negotiations. Forest Policy and Economics, 38, 97-104. http://dx.doi.org/10.1016/j.forpol.2013.08.008

Grundmann, R. (2009). The role of expertise in governance processes. Forest Policy and Economics, 11(5-6), 398-403. http://dx.doi.org/10.1016/j.forpol.2008.09.005

Harian Terbit. (2012a). UE hanya terima kayu SVLK. Retrieved from http://www.harianterbit.com/ 2012/07/24/ue-hanya-terima-kayu-svlk/

Harian Terbit. (2012b). Menhut tolak usulan pengusaha. penerapan sertifikasi kayu tetap 21 Desember. Retrieved from http://www.harian terbit.com/2012/09/12/menhut-tolak-usulan-pengusaha/

Hasanagas, N. D. (2014). Managing information in forest policy networks: Distinguishing the influential actors from the "postmen". Forest Policy and Economics. http://dx.doi.org/10.1016/j.forpol.2014.09.007

Hogl, K., Nordbeck, R., \& Kvarda, E. (2009). When international impulses hit home: The role of domestic policy subsystem configurations in explaining different types of sustainability strategies. Forest Policy and Economics, 11(5-6), 357-364. http://dx.doi.org/10.1016/j.forpol.2008.07.003

Howlett, M., \& Ramesh, M. (1995). Studying public policy: policy cycles and policy subsystems (2nd ed.). Toronto: Oxford University Press.

Humphreys, D. (2006). Logjam: deforestation and the crisis of global governance. London: Earthscan.

Humphreys, D. (2009). Discourse as ideology: Neoliberalism and the limits of international forest policy. Forest Policy and Economics, 11(5), 319-325. http://dx.doi.org/10.1016/j.forpol.2008.08.008

Iben, N., Hansen, C. P., \& Cashore, B. (2014). Timber legality verification in practice: Prospects for support and institutionalization. Forest Policy and Economics, 48, 1-5. http://dx.doi.org/10.1016/j.forpol.2014.11.001

International Tropical Timber Organization [ITTO]. (2011). Annual review and assessment of the world timber situation 2011. Yokohama: International Tropical Timber Organization [ITTO].

Investor Daily Indonesia. (2012). Tak ada sawit indonesia yang merusak lingkungan. Retrieved from http://www.investor.co.id/agribusiness/tak-ada-sawit-indonesia-yang-merusak-lingkungan/39387

Kadjatmiko. (2008). Implementing decentralisation: lessons from experiences in Indonesia. In C. J. P. Colfer, G. 
R. Dahal, \& D. Capistrano (Eds.), Lessons from forest decentralisation: money, justice and the quest for good governance in Asia-Pacific. London: Earthscan.

Kementerian Kehutanan. (2010). Strengthening forest administration. integrative research planning 2010-2014. Document Retrieved from http://forda-mof.org/files/RPI_24_Penguatan_Tatakelola_Kehutanan.pdf

Kementerian Kehutanan. (2012a). Kemenhut launching sistem informasi legalitas kayu. Siaran pers. Retrieved from http://www.dephut.go.id/index.php?q=id/node $/ 8547$

Kementerian Kehutanan. (2012b). Uji pengapalan ekspor produk kayu bersertifikat ke Uni Eropa. Siaran pers. Retrieved from http://www.dephut.go.id/index.php?q=id/node/8649

Kissinger, G., Herold, M., \& De Sy, V. (2012). Drivers of deforestation and forest degradation: A synthesis report for REDD+ policymakers. Vancouver: Lexeme Consulting.

Kleinschmit, D. (2012). Confronting the demands of a deliberative public sphere with media constraints. Forest Policy and Economics, 16, 71-80. http://dx.doi.org/10.1016/j.forpol.2010.02.013

Kompas. (2009). REDD dituntut tidak tinggalkan masyarakat adat. Retrieved from http://nasional.kompas.com/ $\mathrm{read} / 2009 / 12 / 14 / 09421281 /$ REDD.Dituntut.Tidak.Tinggalkan.Masyarakat.Adat

Kompas. (2011a). Riau tuntut dimasukkan dalam REDD Indonesia-Norwegia. Retrieved from http://www.Media-indonesia.com/webtorial/tanahair/?bar_id=MjE3Njkw

Kompas. (2011b). Koordinasi pemerintah buruk. Retrieved from http://www.mediaindonesia.com/ webtorial/tanahair/?bar_id=MjYONDcx

Kompas. (2012a). SVLK cegah praktek log laundering. Retrieved from http://sains.kompas.com/ read/2012/08/01/18175122/svlk.cegah.praktek.log.laundering

Kompas. (2012b). Mantan bupati kampar dituntut 6 tahun penjara. Retrieved from http://cetak.kompas.com/ $\mathrm{read} / 2012 / 10 / 02 / 02490121 /$ mantan.bupati.kampar.dituntut.6.tahun.penjara

Kompas. (2012c). Hutan dirambah, negara rugi ratusan triliun. Retrieved from http://bisniskeuangan. kompas.com/read/2012/10/23/07424761/Hutan.Dirambah.Negara.Rugi.Ratusan.Triliun

Krasner, S. D. (1982). Structural causes and regime consequences: regimes as intervening variables. International Organization, 36(2), 185-205. http://dx.doi.org/10.1017/S0020818300018920

Krott, M. (1990). Öffentliche verwaltung im umweltschutz. ergebnisse einer behördenorientierten policy-analyse am beispiel waldschutz. Wien: Braumüller Verlag.

Krott, M., \& Hasanagas, N. D. (2006). Measuring bridges between sectors: Causative evaluation of $\begin{array}{lllll}\text { cross-sectorality. Forest Policy and } & \text { Economics, }\end{array}$ http://dx.doi.org/10.1016/j.forpol.2005.07.004

Leipold, S. (2014). Creating forests with words-A review of forest-related discourse studies. Forest Policy and Economics, 40, 12-20. http://dx.doi.org/10.1016/j.forpol.2013.12.005

Lindstad, B. H., \& Solberg, B. (2010). Challenges in determining national effects of international policy processes: forest protection in Norway as a case. Forest Policy and Economics, 12(7), 489-496. http://dx.doi.org/10.1016/j.forpol.2010.07.002

Majalah Kehutanan Indonesia. (2008). Dua harimau sumatera kembali ke hutan. 7, 36.

Majalah Kehutanan Indonesia. (2009a). Elang Jawa, burung asli indonesia yang kian hilang. 1, 30-31.

Majalah Kehutanan Indonesia. (2009b). Menteri Kehutanan canangkan pengembangan cendana di NTT. 2, 5-9.

Majalah Kehutanan Indonesia. (2009c). Selayang pandang kawasan konservasi mangrove dan bekantan. 1, 30-31.

Majalah Kehutanan Indonesia. (2010). Norwegia siap kucurkan dana REDD+ USD 1 miliar. 6, 12-13.

Majalah Kehutanan Indonesia. (2011a). Menhut janji kampanyekan legalitas kayu. 11, 5-6.

Majalah Kehutanan Indonesia. (2011b). Promosi kayu legal ala Indonesia-Uni Eropa. 5, 5-7.

Majalah Kehutanan Indonesia. (2011c). Perlu kompensasi nagara maju untuk kurangi GRK. 7, 29-31.

Majalah Kehutanan Indonesia. (2011d). Perdebatan moratorium berakhir. 6, 5-7.

Majalah Swa. (2012). Indonesia sumbang 48\% produksi minyak sawit dunia. Retrieved from http://swa.co.id/ business-research/indonesia-sumbang-48-produksi-minyak-sawit-dunia 
Maryudi, A., Devkota, R. R., Schusser, C., Yufanyi, C., Salla, M. Aurenhammer, H., Rotchanaphatharawit, R., \& Krott, M. (2012). Back to basics: Considerations in evaluating the outcomes of community forestry. Forest Policy and Economics, 14, 1-5. http://dx.doi.org/10.1016/j.forpol.2011.07.017

McDermott, C. L. (2014). REDDuced: From sustainability to legality to units of carbon-The search for common interests in international forest governance. Environmental Science \& Policy, 35, 12-19. http://dx.doi.org/10.1016/j.envsci.2012.08.012

McDermott, C. L., Cashore, B., \& Kanowski, P. (2010a). Global environmental forest policies: An international comparison. London: Earthscan.

McDermott, C. L., Humphreys, D., Wildburger, C., \& Wood, P. (2010b). Mapping the core actors and issues defining international forest governance. In J. Rayner, A. Buck, \& P. Katila (Eds.), Embracing complexity: meeting the challenges of international forest governance. A global assessment report (pp. 19-36). Prepared by the Global Forest Expert Panel on the International Forest Regime. IUFRO World Series Volume 28. Vienna.

Media Indonesia. (2010a). Indonesia surga sawit dunia. Retrieved from http://www.mediaindonesia.com/ webtorial/asianagri/?ar_id=Nzc1Ng

Media Indonesia. (2010b). Internasional akan terus menekan industri sawit. Retrieved from $\mathrm{http} / / /$ www.mediaindonesia.com/webtorial/tanahair/?bar_id=MTc3MDYy

Media Indonesia. (2011a). Indonesia-Uni Eropa ikat perjanjian legalitas perdagangan kayu. Retrieved from http://m.mediaindonesia.com/index.php/read/2011/03/22/212261/21/2/Indonesia-Uni_Eropa_Ikat_Perjanjia n_Legalitas_Perdagangan_Kayu.

Media Indonesia. (2011b). Produk kayu indonesia diakui Uni Eropa. Retrieved from http://www.mediaindonesia.com/read/2011/09/27/263023/4/2/-Produk-Kayu-Indonesia-Diakui-Uni-Eropa.

Media Indonesia. (2011c). Konservasi tambling lampung, bukti keseriusan indonesia cegah pemanasan global. Retrieved from http://www.mediaindonesia.com/read/2011/05/05/222543/89/14/Konservasi-Tambling -Lampung-Bukti-Keseriusan-Indonesia-Cegah-Pemanasan-Global

Media Indonesia. (2012). Otonomi daerah akibatkan penebangan hutan secara sporadis.. Retrieved from http://www. mediaindonesia.com/webtorial/tanahair/?bar_id=MzUxMzg4.

Medina, G., Pokorny, B., \& Weigelt, J. (2009). The power of discourse: hard lessons for traditional forest communities in the Amazon. Forest Policy and Economics, 11(5), 392-397. http://dx.doi.org/10.1016/j.forpol.2008.11.004

Mongabai Indonesia. (2012a). BKSDA Sulut pulangkan seekor macan tutul ke Jawa. Retrieved from http://www.mongabay.co.id/2012/11/15/bksda-sulut-pulangkan-seekor-macan-tutul-ke-jawa/

Mongabai Indonesia. (2012b). Kebijakan moratorium hutan tak cukup hanya dua tahun. Retrieved from http://www.mongabay.co.id/2012/10/01/kebijakan-moratorium-hutan-tak-cukup-hanya-dua-tahun/

Mongabai Indonesia. (2012c). Peta Wilayah Adat Diakomodir Masuk One Map Indonesia. Retrieved from http://www.mongabay.co.id/2012/11/15/peta-wilayah-adat-diakomodir-masuk-one-map/\#ixzz2CGjyh1F1

Nellemann, C., INTERPOL Environmental Crime Programme (Eds.). (2012). Green carbon, black trade: illegal logging, tax fraud and laundering in the worlds tropical forests. A rapid response assessment. United Nations Environment Programme, GRID-Arendal.

Nurrochmat, D. N. (2005). The impacts of regional autonomy on political dynamics, socio-economics and forest degradation: Case of Jambi-Indonesia. Göttingen: Cuvillier.

Nurrochmat, D. R., Dharmawan, A. H., Obidzinski, K., Dermawan, A., \& Erbaugh, J. T. (2014). Contesting national and international forest regimes: Case of timber legality certification for community forests in Central Java, Indonesia. Forest Policy and Economics. http://dx.doi.org/10.1016/j.forpol.2014.09.008

Obidzinski, K., Dermawan, A., Andrianto, A., Komarudin, H., \& Hernawan, D. (2014). The timber legality verification system and the voluntary partnership agreement (VPA) in Indonesia: Challenges for the small-scale forestry sector. Forest Policy and Economics, 48, 24-32. http://dx.doi.org/10.1016/j.forpol.2014.06.009

Ojha, H., Cameron, J., \& Kumar, C. (2009). Deliberation or symbolic violence? The governance of community forestry in Nepal. Forest Policy and Economics, 11, 365-374. http://dx.doi.org/10.1016/j.forpol.2008.11.003 
Ongolo, S. (2015). On the banality of forest governance fragmentation: Exploring "gecko politics" as a bureaucratic behaviour in limited statehood. Forest Policy and Economics. http://dx.doi.org/10.1016/j.forpol.2015.01.005

Overdevest, C., \& Zeitlin, J. (2014a). Assembling an experimentalist regime: Transnational governance interactions in the forest sector. Regulation \& governance, 8(1), 22-48. http://dx.doi.org/10.1111/j.1748-5991.2012.01133.x

Overdevest, C., \& Zeitlin, J. (2014b). Constructing a transnational timber legality assurance regime: Architecture, accomplishments, challenges. Forest Policy and Economics, 48, 6-15. http://dx.doi.org/10.1016/j.forpol.2013.10.004

Peters, B. G. (2010). The politics of bureaucracy-an introduction to comparative public administration (6th ed.). Oxon: Routledge.

Rahman, M. S., \& Giessen, L. (2014). Mapping international forest-related issues and main actors' positions in Bangladesh 1. International Forestry Review, 16(6), 586-601. http://dx.doi.org/10.1505/146554814814095294

Rayner, J., Buck, A. \& Katila, P. (Eds.). (2010). Embracing complexity: meeting the challenges of international forest governance. A global assessment report. Prepared by the Global Forest Expert Panel on the International Forest Regime. Vienna: IUFRO World Series Volume 28. p.172.

Rayner, J., Howlett, M., Wilson, J., Cashore, B., \& Hoberg, G. (2001). Privileging the sub-sector: Critical sub-sectors and sectoral relationships in forest policy-making. Forest Policy and Economics, 2(3-4), 319-332. http://dx.doi.org/10.1016/S1389-9341(01)00038-7

Republika Online (2011a). Gabungan pengusaha sawit keluar dari RSPO. Retrieved from http://www.republika.co.id/berita/nasional/umum/11/10/11/lsvl90-gabungan-pengusaha-sawit-keluar-dari-rs po

Republika Online. (2011b). AS hapus utang RI untuk konservasi hutan. Retrieved from http://www.republika.co.id/berita/ekonomi/keuangan/11/09/29/1s9tz7-as-hapus-utang-ri-untuk-konservasi-hutan

Rimbawan Interaktif. (2012a). Apa kabar SVLK. Message no. 37354.

Rimbawan Interaktif. (2012b). Abstract tentang FLEGT VPA dan SVLK. Message no. 36812-36814.

Rimbawan Interaktif. (2012c). Apa Kabar SVLK [How is SVLK]. Message no 37382.

Rimbawan Interaktif. (2012d). APEC CEO Summit 2012, SBY terus perjuangkan sawit. Message no 36883, 36886 , and 36887.

Rimbawan Interaktif. (2012e). Apa kabar LoI Norway? Message no 36672.

Rimbawan Interaktif. (2012f). Kompas: petisi daring-dari gambut hingga sirip hiu. Message no 37406.

Rimbawan Interaktif. (2012g). Orangutan terbakar saat evakuasi. Message no 37034 and 37035.

Sadath, M. N., \& Krott, M. (2012). Identifying policy change-Analytical program analysis: An example of two decades of forest policy in Bangladesh. Forest Policy and Economics, 25, 93-99. http://dx.doi.org/10.1016/j.forpol.2012.07.013

Sadath, N. (2012). Media as a driver of policy change: The example of forest-climate policy in Bangladesh. (Unpublished doctoral dissertation). University of Goettingen, Goettingen, Germany.

Sadath, N., Kleinschmit, D., \& Giessen, L. (2013). Framing the tiger-A biodiversity concern in national and international media reporting. Forest Policy and Economics, 36, 37-41. http://dx.doi.org/10.1016/j.forpol.2013.03.001

Sahide, M. A. K., \& Giessen, L. (2015). The fragmented land use administration in Indonesia-Analysing bureaucratic responsibilities influencing tropical rainforest transformation systems. Land Use Policy, 43, 96-110. http://dx.doi.org/10.1016/j.landusepol.2014.11.005

Smouts, M. C. (2008). The Issue of an International Forest Regime. International Forestry Review, 10(3), 429-432. http://dx.doi.org/10.1505/ifor.10.3.429

Steffek, J. (2009). Discursive Legitimation in Environmental Governance. Forest Policy and Economics, 11, 313-318. http://dx.doi.org/10.1016/j.forpol.2009.04.003

Suara Merdeka. (2012). Asmindo tolak sertifikasi legalitas kayu. Retrieved from http://www.suaramerdeka.com/ 
v1/index.php/read/news/2012/02/10/109171/Asmindo-Tolak-Sertifikasi-Legalitas-Kayu

Suara Pembaruan. (2012). APEC CEO Summit 2012, SBY terus perjuangkan sawit. Retrieved from $\mathrm{http} / /$ www.suarapembaruan.com/ekonomidanbisnis/apec-ceo-summit-2012-sby-terus-perjuangkan-sawit/24 426

Sunderlin W. D., \& Resosudarmo, I. A. A. P. (1996). Rates and causes of deforestation in Indonesia. Towards a resolution of the ambiguities. CIFOR Occasional Paper no. 9. Bogor: CIFOR.

Suparna, N. (2001). Forest governance and law enforcement in Indonesia. Paper presented at the Forest Law Enforcement \& Governance-East Asia: A Ministerial Conference. Bali, September 11-13.

The Jakarta Post. (2011). Bali starling breeding center opened. Retrieved from http://www.thejakartapost.com/ news/2011/11/09/bali-starling-breeding-center-opened.html

The Jakarta Post. (2012a). Gov't helps small timber product firms get SVLK certification. Retrieved from http://www.thejakartapost.com/news/2012/08/03/govt-helps-small-timber-product-firms-get-svlk-certificati on.html

The Jakarta Post. (2012b). EU postpones approval of RI timber products. Retrieved from http://www.thejakartapost.com/news/2012/09/26/eu-postpones-approval-ri-timber-products.html

The Jakarta Post. (2012c). Govt to counter negative campaign on cpo. Retrieved from $\mathrm{http}: / /$ www.thejakartapost.com/news/2012/04/14/govt-counter-negative-campaign-cpo.html

The Jakarta Post. (2012d). Stamps to spread the word on endangered birds. Retrieved from http://www.thejakartapost.com/news/2012/07/26/stamps-spread-word-endangered-birds.html

UN-REDD. (2012). Indonesia. UN-REDD country brief. Retrieved from http://www.fao.org/climatechange /unredd/53078/en/idn/

Winkel, G. (2007). Waldnaturschutzpolitik in Deutschland. bestandsaufnahmen, analysen und entwurf einer story-line. remagen-oberwinter (Dr. Kessel). Freiburger Schriften zur Forst-und Umweltpolitik 13, 561 p.

\section{Notes}

Note 1. This exploratory study is part and basis of a broader research project, which will subsequently analyse the implementation of the IFRC in Indonesia in more detail.

Note 2. These sources are available in the Internet at http://www. mediaindonesia.com/, http://kompas.com/, and http://www.thejakartapost.com/ respectively.

Note 3. These are available in the Internet at http://www.dephut.go.id/index.php? $\mathrm{q}=\mathrm{id} / \mathrm{node} / 5070$, $\mathrm{http}: / /$ agroindonesia.co.id/ and http://indonesia.mongabay.com/ respectively.

Note 4. Oil palm is the general name term of Elaeis guineensis crop while palm oil is the product that produces from oil palm fruit.

\section{Appendix A}

\section{Main Actors and Their Positions on Each Issue}

\begin{tabular}{lll}
\hline Issue & Main actors & Actors' main positions \\
\hline $\begin{array}{l}\text { Primary international forest-related issues } \\
\text { 1. Timber legality }\end{array}$ & Ministry of Forestry and & - Support FLEGT and VPA \\
& Ministry of Trade & - Produce legal instruments and force industries to \\
& & obey it \\
& & - Promote global recognition of SVLK \\
\cline { 2 - 3 } & Primary and large scale forest & - Support FLEGT and VPA \\
industries & - Willing to be certified \\
\cline { 2 - 2 } & Asmindo, APHI and downstream & - Support FLEGT and VPA \\
industries & - Not willing to be certified \\
& - Downstream industries' products automatically \\
\cline { 2 - 2 } & EU countries (Indonesian wood & - Postponed signing FLEGT and VPA three times \\
\hline
\end{tabular}




\begin{tabular}{|c|c|c|}
\hline \multirow[b]{4}{*}{$\begin{array}{l}\text { 2. Climate change } \\
\text { including REDD } \\
\text { initiative }\end{array}$} & products destination) & - Unclear position \\
\hline & WWF & - Support FLEGT, VPA and SVLK \\
\hline & Researchers and academics & $\begin{array}{ll}- & \text { Distrust EU commitment } \\
- & \text { Bilateral agreements more important than VPA } \\
\text { since the EU agreement is not legally binding } \\
-\quad \text { Push sustainable forest management practice to } \\
\text { build Indonesian wood products' legitimacy } \\
\text { - Warn about SVLK as new gateway for corruption }\end{array}$ \\
\hline & UKP4 and REDD+ Task Force & $\begin{array}{l}\text { - Indonesian representation in international forums } \\
- \text { Much interaction with international actor and less } \\
\text { power }\end{array}$ \\
\hline \multirow{7}{*}{$\begin{array}{l}\text { 3. Oil palm } \\
\text { plantation and its } \\
\text { environmental } \\
\text { aspects }\end{array}$} & Ministry of Forestry & - Technical actor \\
\hline & Scientists & $\begin{array}{l}\text { - Providing studies and conceptual frameworks for } \\
\text { government }\end{array}$ \\
\hline & Ministry of Forestry & - Permits for plantation \\
\hline & Ministry of Trade & $\begin{array}{l}\text { - Fight for acceptance of palm oil products without } \\
\text { any restriction and as a source of national income }\end{array}$ \\
\hline & $\begin{array}{l}\text { Indonesian Palm Oil Association } \\
\text { (GAPKI) }\end{array}$ & - Need to expand oil palm production \\
\hline & Greenpeace and WWF & $\begin{array}{l}\text { - Promote sustainable environment irrespective of } \\
\text { national policy }\end{array}$ \\
\hline & EU and US industries & $\begin{array}{l}\text { - Protect domestic vegetable oil production by } \\
\text { blocking palm oil imports }\end{array}$ \\
\hline \multicolumn{3}{|c|}{ Secondary international forest-related issues } \\
\hline \multirow{4}{*}{$\begin{array}{l}\text { 1. Harmonization of } \\
\text { wood and forest } \\
\text { certification } \\
\text { schemes }\end{array}$} & $\begin{array}{l}\text { Ministry of Forestry } \\
\text { and Ministry of Trade }\end{array}$ & $\begin{array}{ll} & \text { Fight for SVLK in buyer countries } \\
\text { - } & \text { Recognize voluntary scheme and expect the } \\
& \text { opposite for SVLK }\end{array}$ \\
\hline & Indonesian timber industry & $\begin{array}{l}- \text { Want mutual recognition between two kinds of } \\
\text { certification so that they could get both at once }\end{array}$ \\
\hline & $\begin{array}{l}\text { WWF and other environmental } \\
\text { organizations }\end{array}$ & $\begin{array}{l}\text { - Support FSC becoming the powerful and } \\
\text { well-accepted wood and forest certification } \\
\text { scheme }\end{array}$ \\
\hline & $\begin{array}{l}\text { FSC, LEI, PEFC and SVLK } \\
\text { scheme owners }\end{array}$ & $\begin{array}{l}\text { - Fight for their scheme to be recognized by buyers } \\
\text { and accepted by industry }\end{array}$ \\
\hline \multirow[t]{6}{*}{ 2. Land use change } & UKP4 and REDD Task Force & $\begin{array}{l}\text { - Makes policies related to national strategy for } \\
\text { land utilization }\end{array}$ \\
\hline & Ministry of Forestry & $\begin{array}{l}\text { - Maintain control over forest land use } \\
-\quad \text { Keep land use change as their concern } \\
\end{array}$ \\
\hline & Plantation companies (GAPKI) & $\begin{array}{l}- \text { Need to expand oil palm plantation } \\
-\quad \text { Consider restrictions a business obstacle } \\
-\quad \text { Worry about influence of foreign lobby on } \\
\text { Indonesian policy making }\end{array}$ \\
\hline & Indigenous peoples & - Secure their land from occupation by companies \\
\hline & Greenpeace & $\begin{array}{l}\text { - Prohibit Indonesia from utilizing primary and } \\
\text { secondary forests and peat lands }\end{array}$ \\
\hline & Scientists & $\begin{array}{l}\text { - Counsel government to balance economic } \\
\text { development and environmental protection }\end{array}$ \\
\hline \multirow[t]{2}{*}{$\begin{array}{l}\text { 3. Forest and species } \\
\text { conservation }\end{array}$} & Ministry of Forestry & $\begin{array}{l}- \text { Protect genetic resources and consider it a } \\
\text { precious heritage the future }\end{array}$ \\
\hline & $\begin{array}{l}\text { Forest companies and } \\
\text { conservation organizations }\end{array}$ & $\begin{array}{l}\text { - Participate in environmental preservation and } \\
\text { species conservation }\end{array}$ \\
\hline \multirow[t]{2}{*}{$\begin{array}{l}\text { 4. Deforestation and } \\
\text { decentralized }\end{array}$} & $\begin{array}{l}\text { Central government (Ministry of } \\
\text { Forestry) }\end{array}$ & - Secure forest for diplomatic purposes \\
\hline & Local government & - Utilize forest and other idle natural resources as \\
\hline
\end{tabular}


forest governance source of income

WWF, IWGFF, TII $\quad-$ Produce and utilize reports of poor forest management in Indonesia in widespread forums

\section{Appendix B}

\section{Acronyms and Abbreviations}

AMAN Aliansi Masyarakat Adat Nusantara (Indigenous Peoples' Alliance of the Archipelago)

APHI Asosiasi Pengusaha Hutan Indonesia (Association of Indonesian Forest Concessionaires)

Apindo Asosiasi Pengusaha Indonesia (Indonesian Enterprises Association)

Asmindo Asosiasi Industri Permebelan dan Kerajinan Indonesia (Indonesian Furniture Industry and Handicraft Association)

CBD Convention on Biological Diversity

CGI Consultative Group on Indonesia

CIFOR Center for International Forestry Research

EU European Union

FAO Food and Agriculture Organization

FLEGT Forest Law Enforcement, Governance and Trade

FSC Forest Stewardship Council

GAPKI Gabungan Pengusaha Kelapa Sawit Indonesia (Indonesian Palm Oil Association)

IFR International Forest Regime

IFRC International Forest Regime Complex

ISPO Indonesian Sustainable Palm Oil

ITTO International Tropical Timber Organization

MoF Ministry of Forestry

NGO Non-Governmental Organization

PEFC Programme for the Endorsement of Forest Certification

REDD Reducing Emissions from Deforestation and Forest Degradation

RSPO Roundtable on Sustainable Palm Oil

SFM Sustainable Forest Management

SMEs Small and Medium Scale Enterprises

SVLK Sistem Verifikasi Legalitas Kayu (Timber Legality Verification System)

UKP4 Unit Kerja Presiden Bidang Pengawasan dan Pengendalian Pembangunan (Presidential Delivery Unit for Development Monitoring and Oversight)

VPA Voluntary Partnership Agreements

WTO World Trade Organization

WWF World Wide Fund for Nature

\section{Copyrights}

Copyright for this article is retained by the author(s), with first publication rights granted to the journal.

This is an open-access article distributed under the terms and conditions of the Creative Commons Attribution license (http://creativecommons.org/licenses/by/3.0/). 